高い水準にあるが，第 2 週以降，低水準江推移し，逐時 変動も週前半で縮少する。

2)逨続反応時間は，日勤時の逐時的短縮に比し，夜勤 時は逐時的延長傾向を示し，夜勤週を追っても延長の方 向にある。

3） 1 位数加算テストも, 逐時的加算量隇少を認め, 週 を追っても改善さ礼ない。

4) 開眼, 閉眼時の EEG の $\alpha$ 波成分は, 夜勤週を追っ て增高する場合が多く見られた。

5)舌下温の夜間の逐時低下は, 第 2 週以降次籍に逆転 し, 心拍数の早朝徐脉化も持さ光られる傾向を示すが, 血圧の逐週低下, 皮膚電気抵抗の增加が市って, 第 $3 \sim$

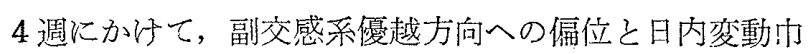
の縮少が推測される。

6)ステップテスト真荷前立位及び回復期脈搏数は, 作 業後 $6{ }^{\circ}$ が作業前 $22^{\circ}$ よりかなり低いレベルにあり，回復期 陰性相も現和水やすい。かかる様相は，週を追っても変 わることなく，負荷後脈搏增加率は低下の傾向を見る。

7)疲学症候や, 昼間睡眠の質にも, 自覚的に改善の傾 向を見ない。

以上の成續は，実験条件にもよろらが，機能水準の 低下, 昼夜波動の平坦化を示唆して和り, 夜勤生活継続 に伴なら一種の適応的変化々も考光られるが, 生理的 には，夜勤の長期継続を可とする゙ものではない。

\section{5. 一連続作業時間と休息について}

沼尻幸吉, 袕田 忠, 野村秀子（労研生理）

筋的作業の場合, 一連続作業時間の長さは学働強度に よって相違する。即号労動強度大なれば作業時間は短か く，小なれば長くなる。労働強度を R MRで示すと，4 以下は定常状態が成立し，これ以上は成立しない之され ている。がしかし，いずれの場合も，作業者の体格，体 カによって，時間因子は同一だとはかぎらない。

種々の産業で, 現場に和ける筋的作業の労働強度と作 業時間との関係をみると, ある関係が成り立っているこ とがわかる。 RMRが 1 程度では, 作業時間が70分以上 となり，休息は作業者が自己休息のかたちでとるのでは なく，工場で定めた時刻にとるようになっている場合が 多い。RMR 2 程度では 30 分, 4 程度では, 15 18分, 7 では 5 分程度が一連続作業時間之なっている。現場で の作業時間は，作業そのものの制約からくる場合もある ことを忘れてはならない。この上らなことを考虑に入れ て，一連続作業時間をみたのが，前述の值である。

さて, 種々の労㗢強度での一連続作業時間後, 休息時
間をどの程度の長さにすべきが，重要であり，困難な 問題である。いま筋的作業の回復を, 呼気量, 酸素消費 量, 脈搏数の変化なぞで観察してみると, 脈搏数で代表 されるよらに思う。それで作業, 回復を通じて, 脈搏数 を連続記録, 観察した。ただし脈搏数は労働強度が大き いか，小さくとも作業時間が長い場合は, 作業前の安静 值にもどらない場合が多い。それで安静時の $10 \%$ 增（散 歩), 15\%增（歩行）程度で, plateau となった場合を 限度として，休息時間の長さをかりに定めてみると， RMR 2 程度では，前者が作業時間の $5 \%$ ，後者は $5 \%$ ， 4 では前者 $40 \%$ ，後者 $28 \% ， 7$ では $120 \% ， 90 \%$ 前後と なる。前者での 8 時間労働量は $1,400 \mathrm{Cal}$, 後者では 1,800 $\mathrm{Ca}$ 程度で, 後者の労働量は, 演者らが一応, 労働量の 限界として述べている值と一致している。

\section{6. 生体諸反応の無線搬送に関する研究}

(第 2 報) FM-AM 方式による cardiotachogram の無線搬送について

白石信尚, 橋本邦衛, 堀米真一, 千田英三, 菅田勋和，田中勝次 (日大公衛)

胸部双極誘導により誘導したECGをフフローティン グインプット方式の前置堌幅器により增巾し, これで2 $\mathrm{KC}$ のマルチバイブレーターの発振周波数を制御して, 周波数变調を行ない副搬送波を得る。水晶制御発振器で 発生した 27.12MC の主搬送波を，この副搬送波で振幅 変調して, アンテナより送信する。

受信器側では, 水晶制御スーパーヘテロダィンによ り，455KCの中間周波に拈とし，検波してえられる副般 送波を增巾したのち，Foster-Seely 検波器により，も との ECG になおしたのち, 雑音制御回路で R一spike のみをとりだしここれ trigger としてサイラトロン を制御し，えられる出力をペンレコーダーで記録した。 ペン振巾は心搏間隔に比例する。

本装置は，完全にトランジスタ化されているために， 小型軽量で操作容易, 動作確実であるのみならず, 受信 側で雑音抑制回路を調整することにより，R-spikeだけ をとりだすことができるので, 信号雑音比のわるい時で も，良好な情報をらることができる。

また前回報告したAM方式とことなり，各種生体反応 を副搬送波の周波数带を適当にか觉ることにより，同一 の主搬送波に，同時にのせて送信することができる。す なわち同時多重通信が可能である。

本装置を用いて記録した重量負荷歩行時の心搏数の变 動についても，あわせて報告する。 